\title{
Screening for BPPV in falls: an easy but big clinical "win"
}

\section{Barry M Seemungal consultant neurologist/neuro-otologist and senior lecturer}

St Mary's and Charing Cross Hospitals, Division of Brain Sciences, Imperial College London W6 8RF, UK

It is surprising that Vieira and colleagues do not mention benign paroxysmal positional vertigo (BPPV) in their article on falls' prevention in older people. ${ }^{1} \mathrm{BPPV}$ causes falls, ${ }^{2}$ it is common - affecting about $10 \%$ of older people ${ }^{3}$ it can be cured in over $80 \%$ of cases with standard two minute clinical manoeuvres, ${ }^{4}$ and treating BPPV in older people reduces falls. ${ }^{5}$ Many patients do not have a sensation of vertigo with BPPV, ${ }^{6}$ which partly explains why $10 \%$ of unbalanced older patients in the community had unrecognised BPPV. ${ }^{1}$ Additionally, some clinicians may be hesitant to use the clinical manoeuvres that diagnose (and treat) BPPV in elderly patients on safety grounds. These clinical manoeuvres, however, can be adapted to accommodate frailty without sacrificing clinical efficacy. ${ }^{78}$ It is time that local and national guidelines recognise this missed clinical opportunity and explicitly call for screening for BPPV in all older people with falls. ${ }^{9}$

Competing interests: None declared.
1 Vieira ER, Palmer RC, Chaves PHM. Prevention of falls in older people living in the community. BMJ 2016;353:11419. doi:10.1136/bmj.i1419 pmid:27125497.

2 Oghalai JS, Manolidis S, Barth JL, Stewart MG, Jenkins HA. Unrecognized benign paroxysmal positional vertigo in elderly patients. Otolaryngol Head Neck Surg 2000;122:630-4.pmid:10793337.

3 von Brevern M, Radtke A, Lezius F, et al. Epidemiology of benign paroxysmal positional vertigo: a population based study. J Neurol Neurosurg Psychiatry 2007;78:710-5. doi:10. 1136/jnnp.2006.100420 pmid:17135456

4 Prokopakis E, Vlastos IM, Tsagournisakis M, Christodoulou P, Kawauchi H, Velegrakis G. Canalith repositioning procedures among 965 patients with benign paroxysmal positional vertigo. Audiol Neurootol 2013;18:83-8. doi:10.1159/000343579 pmid:23147839.

5 Ganança FF, Gazzola JM, Ganança CF, Caovilla HH, Ganança MM, Cruz OL. Elderly falls associated with benign paroxysmal positional vertigo. Braz J Otorhinolaryngol 2010;76:113-20.pmid:20339699

6 Imbaud Genieys S. [Vertigo, dizziness and falls in the elderly]Ann Otolaryngol Chir Cervicofac 2007;124:189-96. doi:10.1016/j.aorl.2007.04.003 pmid:17761136.

7 Kollén L, Frändin K, Möller M, Fagevik Olsén M, Möller C. Benign paroxysmal positional vertigo is a common cause of dizziness and unsteadiness in a large population of 75-year-olds. Aging Clin Exp Res 2012;24:317-23. doi:10.1007/BF03325263 pmid: 23238307.

8 NHS. London Clinical Networks. Video guide: adults with dizzy spells. 2016. http://www. Iondonscn.nhs.uk/publication/adults-with-dizzy-spells-edu-videos/.

9 National Institute for Health and Care Excellence. Falls in older people: assessing risk and prevention. NICE guideline 161. 2013. https://www.nice.org.uk/guidance/cg161.

Published by the BMJ Publishing Group Limited. For permission to use (where not already granted under a licence) please go to http://group.bmj.com/group/rights-licensing/ permissions 